\title{
Pengembangan Produk Souvenir Sabun Padat Menggunakan Minyak Goreng Sawit pada Ibu PKK Kelurahan Rawamangun Jakarta Timur
}

\author{
Suherman \\ Universitas Negeri Jakarta, $\underline{\text { suherman@unj.ac.id }}$ \\ Andrian Haro \\ Universitas Negeri Jakarta, andrian.haro@unj.ac.id \\ Sholatia Dalimunthe \\ Universitas Negeri Jakarta, tiadalimunthe@unj.ac.id
}

\begin{abstract}
Nowadays, solid and transparent soap is often used as a display of wedding souvenirs, air freshener, and handicrafts. With the presence of a solid and transparent soap in very unique display and interesting this can make the soap is sold at a relatively more expensive price in the market. Regarding with the development of solid soap products that can produce several good benefits, this activity needs to be trained, developed and empowered to the parties who have the potential to produce these product. One of the parties that has the potential to be trained is the housewives in the PKK group (Family Welfare Empowerment) at Rawamangun, East Jakarta. This community service activity is done by using lecture and simulation/demonstration method through innovative product development of souvenir soap by using palm cooking oil. The results of the training show the enthusiasm and willingness of the participants to be able to perform individually in the manufacture of solid soap souvenir products and they can produce in large quantities. With this training, the housewives can practice themselves at home and be motivated to open business opportunities through these product so it can be feasible for sale in the market.
\end{abstract}

Key word: Product development, Empowerment, Innovation, Solid soap

\section{PENDAHULUAN}

\section{Analisis Situasi}

Salah satu produk perawatan rumah tangga (personal care) yang menggunakan bahan dasar minyak dan sangat sering digunakan oleh masyarakat adalah sabun. Produk sabun ini ternyata memiliki peluang untuk dikembangkan lebih lanjut tidak sekedar sebagai produk pembersih kulit, akan tetapi bisa difungsikan menjadi beraneka ragam kegunaan. Saat ini, keragaman produk sabun tersebut berkembang sejalan dengan perubahan gaya hidup dan kebutuhan atau keinginan konsumen terhadap produk sabun tersebut. Oleh karena itu, selaku produsen harus terus melakukan 
pengembangan dan inovasi produk supaya bisa menarik perhatian konsumen dan membuat mereka tetap melakukan pembelian atas produk tersebut (Rini, 2013).

Pengelompokkan produk sabun dibedakan menjadi dua jenis, yaitu sabun cair dan sabun padat (batangan). Kedua jenis sabun tersebut sangat beragam sekali mulai dari bentuk, aroma, warna, dan manfaat yang ditawarkan. Kategori dari sabun padat (batangan) ini dibedakan menjadi sabun opaque, sabun transcluent, dan sabun transparan, dimana tingkat transparansinya menjadi pembeda dari ketiga jenis sabun tersebut. Sabun opaque memiliki tingkat transparansi atau ketampakan yang tidak transparan dibandingkan sabun transcluent dan sabun transparan

Umumnya dipasaran saat ini jenis sabun transparan menjadi salah satu produk sabun unggulan yang telah meluas kegunaannya. Dewasa ini, sabun padat dan transparan sering dimanfaatkan sebagai pajangan souvenir pernikahan, pengharum ruangan, dan kerajinan tangan. Perkembangan dari produk sabun padat dan transparan tersebut dikarenakan produk itu dapat dibuat sesuai dengan selera, kreativitas dan keinginan seorang konsumen. Dengan keberadaan dari tampilan sabun padat dan transparan yang menarik inilah dapat membuat sabun tersebut dijual dengan harga yang relatif lebih mahal dipasaran. Terkait dengan pengembangan produk sabun padat tersebut yang dapat menghasilkan keuntungan, kegiatan ini perlu dilakukan pelatihan, pembinaan dan pemberdayaan kepada pihak-pihak yang berpotensi untuk mengembangkan produk tersebut. Salah satu pihak yang memiliki potensi untuk dibina dan dilatih adalah para ibu rumah tangga pada kelompok ibu PKK (Pemberdayaan Kesejahteraan Keluarga). Hal ini dikarenakan kegiatan utama PKK adalah untuk memajukan dan meningkatkan taraf hidup perekonomian keluarga, pendidikan, dan kesehatan, dimana para anggotanya sebagian besar adalah ibu rumah tangga (Haro, Waspodo, dan Handaru, 2017). Melalui kegiatan pengabdian pada masyarakat ini diharapkan dapat memberikan keterampilan kepada ibu rumah tangga pada kelompok ibu PKK 
RT 003/008 kelurahan Rawamangun, Jakarta Timur, melalui pengembangan produk inovatif souvenir sabun padat menggunakan minyak goreng sawit. Dengan adanya pelatihan ini, para ibu rumah tangga termotivasi untuk membuka peluang bisnis melalui produk tersebut sehingga bisa layak untuk dijual dipasaran.

\section{Perumusan Masalah}

Berdasarkan analisis situasi di atas, maka perumusan masalah adalah bagaimana cara meningkatkan keterampilan ibu rumah tangga pada kelompok ibu PKK RT 003/008 kelurahan Rawamangun, Jakarta Timur, melalui pengembangan produk inovatif souvenir sabun padat menggunakan minyak goreng sawit?

\section{Tujuan Kegiatan}

Tujuan pengabdian masyarakat ini adalah untuk meningkatkan keterampilan ibu rumah tangga pada kelompok ibu PKK RT 003/008 kelurahan Rawamangun, Jakarta Timur, melalui pengembangan produk inovatif souvenir sabun padat menggunakan minyak goreng sawit.

\section{Manfaat Kegiatan}

Dengan diadakan kegiatan pengabdian pada masyarakat ini, diharapkan memberikan manfaat kepada peserta antara lain:

1. Meningkatkan keterampilan bagi ibu rumah tangga pada kelompok ibu PKK RT 003/008 kelurahan Rawamangun, Jakarta Timur, melalui pengembangan produk inovatif souvenir sabun padat menggunakan minyak goreng sawit.

2. Meningkatkan motivasi ibu rumah tangga pada kelompok ibu PKK RT 003/008 kelurahan Rawamangun, Jakarta Timur, untuk menjadikan keterampilan yang mereka peroleh sebagai peluang bisnis keluarga sehingga dapat membantu meningkatkan pendapatan rumah tangga mereka.

\section{KAJIAN TEORITIK}

\section{Pemberdayaan}

Pemberdayaan adalah sebuah proses untuk meningkatkan kemampuan manusia/masyarakat menjadi berdaya baik pengetahuan dan ketrampilan. Para ahli menyatakan pemberdayaan upaya untuk meningkatkan harkat dan 
martabat lapisan masyarakat yang dalam kondisi sekarang tidak mampu untuk melepaskan diri dari perangkap kemiskinan dan keterbelakangan. Dengan kata lain pemberdayaan adalah memampukan dan memandirikan masyarakat. Agar menghasilkan manusia yang mampu dan mandiri diperlukan proses terhadap manusianya baik secara individu maupun kelompok. Berdasarkan ini maka bertujuan untuk: Pertama, memenuhi kebutuhan dasar masyarakat sehingga mereka memiliki kebebasan (freedom), dalam arti bukan saja bebas mengemukakan pendapat, bebas dari kelaparan, bebas dari kebodohan atau bebas dari kesakitan. Kedua, menjangkau sumber produktif atau bebas yang memungkinkan masyarakat dapat meningkatkan pendapatannya serta memperolah barang-barang dan jasa yang perlukan. Ketiga, berpartisipasi dalam proses pembangunan dan keputusan-keputusan yang mempengaruhi mereka.

\section{Pengembangan Produk}

Pengembangan produk dapat dikatakan sebagai rangkaian aktivitas yang dimulai dari analisis persepsi dan peluang pasar, yang nantinya diakhiri dengan tahap produksi, penjualan, dan pengiriman suatu produk (Ulrich dan Steven, 2001). Tiga fungsi yang memiliki peranan penting dalam pengembangan produk, antara lain:

1. Pemasaran

Fungsi pemasaran memfasilitasi hubungan interaksi antara perusahaan dengan pelanggan. Selain itu, fungsi ini berperan dalam proses identifikasi peluang produk, pendefinisian segmen pasar, dan identifikasi kebutuhan pelanggan. Bagian pemasaran juga bertugas untuk merancang komunikasi antara perusahaan dengan pelanggan, menetapkan target harga dan merancang peluncuran serta promosi produk.

2. Perancangan (design)

Fungsi perancangan memiliki peranan penting dalam mendefinisikan sebuah bentuk fisik produk agar dapat memenuhi kebutuhan pelanggan. Dalam konteks tersebut tugas bagian perancangan mencakup desain engineering dan desain industri.

\section{Manufaktur}

Fungsi manufaktur bertanggung jawab dalam merancang dan mengoperasikan sistem produksi pada proses produksi 
sebuah produk. Fungsi manufaktur mencakup proses dalam pembelian, distribusi dan instalasi.

Sedangkan menurut Kotler dan Keller (2016), pengembangan produk adalah sebuah pengembangan konsep produk yang diwujudkan menjadi produk nyata, dimana untuk memastikan bahwa ide produk dapat di ubah menjadi produk yang bisa dikerjakan. Pengembangan produk merupakan strategi pemasaran yang memerlukan penciptaan produk baru yang dapat dipasarkan, proses merubah aplikasi untuk teknologi baru ke dalam produk yang dapat dipasarkan. Terdapat empat tipe dasar dalam program pengembangan produk, yaitu :

1. Modifikasi produk lini

2. Produk substitusi

3. Produk komplemen

4. Produk Inovasi

\section{Inovasi Produk}

Inovasi produk merupakan gabungan dari berbagai macam proses yang saling mempengaruhi antara yang satu dengan yang lain (Kotler dan Keller, 2016). Maka dapat digambarkan bahwa inovasi bukanlah sebuah konsep dan ide baru, penemuan baru ataupun suatu perkembangan dari suatu pasar yang baru, melainkan inovasi merupakan gambaran dari semua proses-proses tersebut. Inovasi adalah salah satu faktor penting dalam meningkatkan keuntungan, positioning, dan kinerja bagi perusahaan dalam menghadapi dinamika pasar. Dengan melakukan inovasi, perusahaan akan bereaksi terhadap perubahan pasar yang dinamis sehingga mampu menciptakan atau mempertahankan daya saingnya dipasaran.

Inovasi produk dapat berasal dari keinginan konsumen akan suatu produk untuk dapat memenuhi kebutuhannya (market pull). Biasanya inovasi yang muncul dari market pull/demand pull bersumber dari ketidakpuasan konsumen atas suatu produk di pasar, sehingga menciptakan pemecahan masalah atas permintaan konsumen tersebut. Dorongan ini berasal dari seseorang atau sekelompok orang yang ingin mengekspresikan kebutuhan pasar menjadi produk nyata sehingga dapat digunakan oleh banyak orang yang membutuhkannya.

Selain itu, inovasi produk bisa muncul dikarenakan suatu teknologi 
yang telah menciptakan atau mengembangkan sebuah produk baru yang kemudian diperkenalkan ke dalam pasar (technology push). Inovasi ini bermula dari ketidakpuasan peneliti akan produk yang sudah ada sehingga menyebabkan peneliti bermaksud untuk mengkomersialisasikan produk baru yang belum dimengerti oleh masyarakat. Dorongan ini datang dari kompetensi teknologi yang dapat diaplikasikan. Dorongan seperti ini tidak melihat potensi pasar apakah penciptaan produk tersebut dibutuhkan sebelumnya oleh pasar atau tidak.

\section{MATERI DAN METODE}

\section{Realisasi Pemecahan Masalah}

Untuk mendapatkan target atau sasaran yang tepat dalam kegiatan pengabdian pada masyarakat ini, perlu dilakukan observasi dan wawancara kepada ibu-ibu rumah tangga pada kelompok ibu PKK RT 003/008 kelurahan Rawamangun. Hal ini dimaksudkan agar kondisi profil keluarga atau peserta bisa dikelompokkan ke dalam satu bagian sehingga proses kegiatan pengabdian pada masyarakat yang berupa pengembangan produk inovatif souvenir sabun padat menggunakan minyak goreng sawit dapat tersampaikan dengan baik. Tentunya kesiapan dalam memberikan materi pelatihan yang dapat dimengerti oleh peserta sudah dipersiapkan oleh panitia melalui metode ceramah dan simulasi. Selain itu, metode demontrasi langsung dihadapan peserta akan dilakukan pada tahap pembuatan dan pengembangan produk inovatif souvenir sabun padat yang menggunakan minyak goreng sawit.

\section{Khalayak Sasaran}

Sasaran dalam kegiatan pengabdian pada masyarakat ditujukan kepada ibu rumah tangga pada kelompok ibu PKK RT 003/008 kelurahan Rawamangun di daerah Jakarta Timur. Dapat digambarkan bahwa latar belakang pendidikan para ibu rumah tangga yang masih rendah dan tingkat perekonomian keluarga yang tergolong ke dalam masyarakat ekonomi menengah sangatlah tepat untuk dijadikan sebagai sasaran dalam kegiatan ini. Diharapkan dengan adanya kegiatan ini memberikan kemampuan dan keterampilan bagi ibu rumah tangga pada kelompok ibu PKK kelurahan 
Rawamangun untuk menciptakan sebuah produk inovatif berupa souvenir sabun padat menggunakan minyak goreng sawit yang nantinya produk tersebut dapat dijual kepasaran dan membuka peluang bisnis serta dapat meningkatkan pendapatan rumah tangga.

\section{Waktu Dan Tempat Kegiatan}

Kegiatan pengabdian pada masyarakat ini dilakukan pada tanggal 17 Oktober 2017 yang bertempat di kelurahan Rawamangun, Jakarta Timur. Para peserta dalam acara ini adalah kelompok ibu PKK di kelurahan Rawamangun.

\section{Metode Penerapan}

Kegiatan pengabdian pada masyarakat ini menerapkan metode ceramah dan simulasi/demonstrasi. Pada tahap pengembangan produk inovatif souvenir sabun padat, cara yang sangat tepat dilakukan adalah melalui demonstrasi atau praktik langsung dihadapan peserta. Dengan metode demonstrasi inilah diharapkan secara optimal kepada para peserta untuk mempelajari, mengingat, memahami, dan mampu melakukan kembali tahapan dalam pengembangan produk inovatif souvenir sabun padat yang menggunakan bahan baku minyak goreng sawit. Hal tersebut dikarenakan para peserta secara langsung melihat tahap demi tahap dalam proses pembuatan souvenir sabun padat mulai dari awal hingga produk itu siap dikemas, dimana tiap tahapannya hampir menyerupai proses dalam memasak atau membuat adonan kue yang biasa dilakukan para ibu rumah tangga.

\section{PEMBAHASAN DAN HASIL}

\section{Pembahasan}

$$
\begin{array}{r}
\text { Pelatihan ini menggunakan } \\
\text { teknik demonstrasi atau praktik }
\end{array}
$$
langsung dihadapan para peserta ibu rumah tangga. Namun, sebelum pelatihan ini dilakukan terlebih dahulu diberikan penjelasan secara singkat terkait penggunaan bahan baku, fungsi dari bahan baku, dan harga dari bahan baku yang akan digunakan dalam pembuatan produk inovatif sabun padat. Untuk informasi tentang formulasi dan harga pembuatan produk inovatif sabun padat, selengkapnya dapat dilihat pada tabel 4.1. 
Tabel 4.1. Formulasi dan Harga

Pembuatan Sabun Padat

\begin{tabular}{|c|c|c|}
\hline Bahan & Berat & Harga \\
\hline Minyak Sawit & 490 gram & $\operatorname{Rp} 6.500$ \\
\hline $\begin{array}{c}\text { Sodium } \\
\text { Hidroksida/ } \\
\text { Soda Api }\end{array}$ & 75,5 gram & $\operatorname{Rp} 2.300$ \\
\hline Air Destilasi & 210 gram & - \\
\hline $\begin{array}{c}\text { Parfum/ } \\
\text { essential oil }\end{array}$ & $10 \mathrm{ml}$ & Rp 20.000 \\
\hline $\begin{array}{c}\text { Pewarna } \\
\text { Sintetik Bubuk }\end{array}$ & Menyesuaikan & Rp 500 \\
\hline & \multicolumn{2}{|c|}{$\begin{array}{l}\text { Total sabun padat yang } \\
\text { dihasilkan: } 12 \text { pcs (satuan) } \\
\sim \text { Total harga sabun padat: } \\
\text { Rp 29.300/12 pcs } \approx \\
\text { Rp } 2.450 / \text { pcs }\end{array}$} \\
\hline
\end{tabular}

Sumber: Data diolah peneliti (2017)

Bahan-bahan dalam pembuatan produk inovatif sabun padat ini mudah untuk didapatkan. Bahan-bahan tersebut cukup dikenal oleh peserta. Akan tetapi ada beberapa bahan yang harus dibeli di toko kimia yaitu soda api, pewarna sintetik, dan parfum. Peserta diperkenalkan dengan bahan-bahan dalam pembuatan produk inovatif sabun padat. Peserta juga dijelaskan fungsi dari bahan-bahan tersebut dalam pembuatan sabun padat seperti misalnya fungsi parfum sebagai pewangi dalam sabun padat. Tahapan proses pembuatan sabun padat ini sangat mudah dan sederhana, tahap-tahap dalam pembuatan sabun padat adalah:

1. Tuangkan minyak sawit ke dalam blender

2. Larutkan soda api ke dalam air yang sudah disiapkan dalam wadah

3. Campurkan larutan soda api ke dalam blender yang sudah ada minyak

4. Tambahkan parfum dan pewarna ke dalam campuran tersebut

5. Aduk hingga semua merata kira-kira 5-10 menit

6. Apabila campuran sudah terlihat kental hentikan pengadukan

7. Tuangkan campuran ke dalam cetakan yang telah siap

8. Diamkan selama beberapa hari baru keluarkan dari cetakannya

9. Masukkan ke dalam kemasan yang akan dijadikan souvenir

Akan tetapi, pembuatan sabun padat ini diperlukan kehati-hatian dikarenakan adanya bahan soda api yang dapat membuat tangan perih jika terkena langsung. Oleh karena itu, peserta diharapkan menggunakan sarung tangan dan masker ketika membuat sabun padat tersebut. 
Hasil

Hasil pelatihan ini mendapat respon baik dari para peserta. Peserta tersebut sangat antusias dan menyimak dengan baik informasi yang diberikan serta aktif bertanya terkait proses pembuatan sabun padat ini, seperti terlihat pada gambar 4.2.

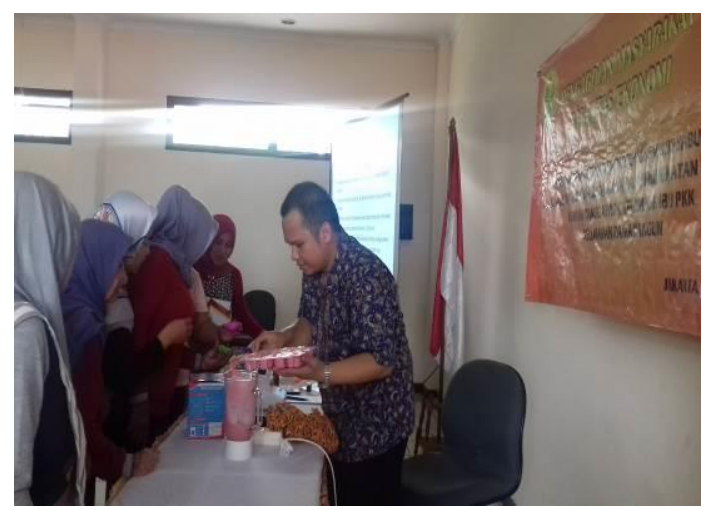

Gambar 4.2. Pelatihan Pembuatan

Produk Inovatif Sabun Padat

Di dalam proses pembuatan sabun padat ini tentunya memerlukan waktu pendinginan di suhu kamar kurang lebih paling cepat 1 hari supaya hasil cetakan sabun padat dapat segera terbentuk. Akan tetapi, hasil pendinginan sabun padat ini akan lebih baik jika didiamkan dalam waktu 1 sampai dengan 2 minggu agar hasil yang diperoleh bisa optimal. Di bawah ini, beberapa hasil pembuatan sabun padat yang telah dibentuk menjadi sebuah produk souvenir yang terlihat pada gambar 4.3.

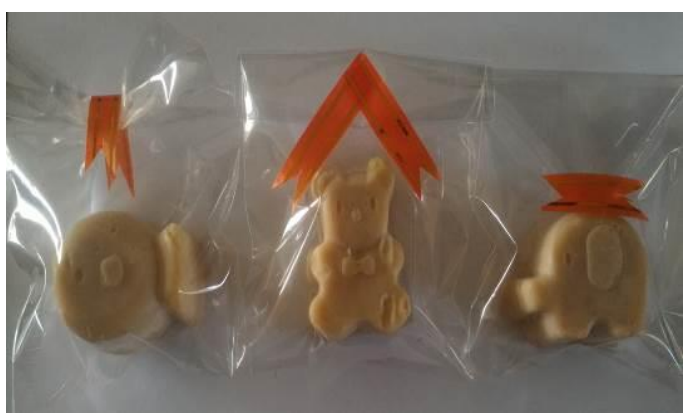

Gambar 4.3. Produk Inovatif Souvenir Sabun Padat

Beberapa peserta menanyakan apakah ada perbedaan bahan jika sabun tersebut adalah sabun cair, atau pertanyaan seperti bagaimana jika minyak sawitnya merupakan minyak goreng bekas atau jelantah. Ada peserta yang juga memberi saran seperti pelatihan membuat aroma terapi mengingat banyak peserta yang menjadi lebih tertarik lagi dengan pembuatan produk lain.

Pelatihan ini memberikan pengetahuan kepada ibu rumah tangga tentang pembuatan produk inovatif sabun padat yang dapat dijadikan souvenir. Pelatihan ini memacu peserta untuk mengembangkan jiwa 
berwirausaha dengan menggunakan bahan rumah tangga seperti minyak sawit karena minyak sawit dapat berupa minyak yang sudah terpakai dengan syarat masih satu kali pemakaian. Produk sabun padat ini tidak hanya dapat dijadikan souvenir akan tetapi dapat digunakan sendiri oleh peserta. Dengan adanya kegiatan ini, para ibu rumah tangga menjadi terbuka wawasannya dan termotivasi untuk menjadikan keterampilan yang mereka peroleh sebagai usaha sampingan atau bisnis rumah tangga (home industry) dalam membantu perekonomian rumah tangga mereka.

\section{KESIMPULAN DAN SARAN}

\section{Kesimpulan}

Berdasarkan uraian diatas, maka dapat disimpulkan hasil kegiatan pengabdian pada masyarakat, yaitu:

1. Pelatihan ini memberikan peningkatan keterampilan peserta ibu rumah tangga PKK kelurahan Rawamangun yang ditunjukkan dengan antusiasme dan kemauan peserta untuk dapat tampil secara individual dalam pembuatan produk souvenir sabun padat dan mereka berkeinginan dapat menghasilkan produk dalam jumlah banyak.

2. Dengan adanya pelatihan ini, para ibu rumah tangga termotivasi untuk membuka peluang bisnis melalui produk tersebut sehingga bisa layak untuk dijual dipasaran.

\section{Saran}

Berikut ini saran yang dapat diberikan dalam peningkatan kualitas kegiatan pengabdian pada masyarakat, diantaranya:

1. Melakukan evaluasi kembali dalam kurun waktu 3 sampai dengan 6 bulan terhadap peserta pelatihan ibu PKK Kelurahan Rawamangun, Jakarta Timur, terkait dengan pelatihan pembuatan sabun padat. Apakah pelatihan yang diberikan dimanfaatkan sebagai salah satu alternatif usaha untuk meningkatkan ekonomi keluarga?

2. Kegiatan pengabdian pada masyarakat ini dapat dilanjutkan dengan melakukan pengembangan dan inovasi produk lainnya yang dapat memberikan peluang bisnis, salah satunya produk aroma terapi. 


\section{DAFTAR PUSTAKA}

Haro, A., Waspodo, A. AWS., dan Handaru, A. W. 2017. Peningkatan Keterampilan Bagi Ibu Rumah Tangga dalam Rangka Penghematan Melalui Pembuatan Sabun Cair Sederhana. Jurnal Pemberdayaan Masyarakat Madani, Vol. 1, No. 2, pp. 194206.

Kotler, P. dan Keller, K. L. 2016. Marketing Management $16^{\text {th }}$ edition. New Jersey: Pearson.

Rini, E. S.. 2013. Peran Pengembangan Produk Dalam Meningkatkan Penjualan. Jurnal Ekonom, Vol. 16, No. 1, pp. 30-38.

Ulrich, K. T. dan Steven D. E. 2001. Perancangan dan Pengembangan Produk, Edisi 1. Jakarta: Salemba Teknika. 